\section{Public Health} Genomics
Public Health Genomics 2010;13:55-62

DOI: $10.1159 / 000218710$
Received: October 31, 2008

Accepted: March 3, 2009

Published online: May 13, 2009

\title{
When Is a Genetic Test Suitable for Prime Time? Predicting the Risk of Prostate Cancer as a Case-Example
}

\author{
A. Li-Wan-Po P. Farndon C. Cooley J. Lithgow
}

National Genetics Education and Development Centre, Morris House, Birmingham Women's Hospital, Birmingham, UK

\section{Key Words}

Clinical validity $\cdot$ Gene expression signature .

Pharmacogenetics $\cdot$ Test validation $\cdot$ Translational research

\begin{abstract}
Advances in genomics promise to deliver personalized medicine both for prevention and treatment of disease. Considerable effort is being directed towards translating observed associations between various genetic variants, such as single nucleotide polymorphisms (SNPs), and disease or drug response into clinically useful genetic tests. Unfortunately, because reported associations are usually weak or moderate, tests based on them are generally not accurate enough for use in routine clinical practice, and therefore, ensuring the appropriate use of genetic tests is important. In a recent report, a combination of 5 SNPs was claimed to improve the predictive value of the test for prostate cancer, compared with the individual SNPs. This led the authors to suggest that a 5-SNP-test could be used to predict the risk of prostate cancer. We evaluate the characteristics of the proposed test, comment on it, and summarize the views of others on its potential clinical utility. We hope that this may serve as a caseexample for the evaluation of the many new genetic tests being suggested for adoption. Copyright $\odot 2009 \mathrm{~S}$. Karger AG, Basel
\end{abstract}

\section{KARGER}

Fax +4161306 1234

E-Mail karger@karger.ch

www.karger.com (c) 2009 S. Karger AG, Basel

$1662-4246 / 10 / 0131-0055 \$ 26.00 / 0$

Accessible online at:

www.karger.com/phg
Given the increasing number of genetic tests being developed, ensuring their appropriate use is important [1]. Prostate cancer is the most common cancer in men in Europe and North America. A recent Swedish study with a prospective follow-up of over 20,000 men, aged 33 to 50 years, over a period of 13 to 25 years identified 498 cases of prostate cancer (2.3\%) [2]. Four years later, this number had increased to $4.9 \%$ [3]. Indeed, the incidence of prostate cancer increases exponentially with age, with the sharpest increase from about the 5 th to the 8 th decade [4]. In addition to age, race and family history are also recognized risk factors for prostate cancer $[5,6]$. The reported incidence rates of prostate cancer differ by as much as 90 fold between populations [4]. Given the high incidence of prostate cancer, particularly in much of the developed world, it is not surprising that there is great interest in the use of screening to identify those at high risk of developing the disease, and research funding for the disease has increased accordingly. Measurement of blood prostate specific antigen (PSA) is currently the most widely used screening method for prostate cancer. Although a high level of PSA is a powerful predictor of risk of prostate cancer, PSA is, in many respects, still an unsatisfactory biomarker because increased PSA levels are also associated with conditions such as prostate inflammation and be- 
Table 1. SNPs chosen for test development

\begin{tabular}{|c|c|c|c|c|}
\hline SNP & $\begin{array}{l}\text { Chromo- } \\
\text { somal region }\end{array}$ & $\begin{array}{l}\text { Alternative } \\
\text { alleles }\end{array}$ & $\begin{array}{l}\text { Risk associ- } \\
\text { ated allele }\end{array}$ & $\begin{array}{l}\text { - Odds ratio } \\
(95 \% \mathrm{CI})\end{array}$ \\
\hline rs4430796 & $17 q 12$ & $\mathrm{~T}, \mathrm{C}$ & $\mathrm{T}$ & $1.24(1.14-1.36)$ \\
\hline rs1859962 & $17 \mathrm{q} 24.3$ & $\mathrm{G}, \mathrm{T}$ & G & $1.17(1.08-1.28)$ \\
\hline rs16901979 & $8 q 24$ & $\mathrm{C}, \mathrm{A}$ & $\mathrm{A}$ & $1.65(1.33-2.05)$ \\
\hline rs6983267 & $8 q 24$ & $\mathrm{G}, \mathrm{T}$ & G & $1.22(1.12-1.33)$ \\
\hline rs1447295 & $8 q 24$ & $\mathrm{C}, \mathrm{A}$ & $\mathrm{A}$ & $1.21(1.07-1.36)$ \\
\hline
\end{tabular}

nign prostatic hyperplasia [7]. False-positive results lead to unnecessary biopsies and work-up as well as potentially unhelpful chemoprophylaxis [8]. Although no study has yet convincingly shown that prostate cancer screening with PSA reduces mortality, over half the men in the United States, aged 50 and over, recently reported participating regularly $[9,10]$. The PSA threshold to refer patients for a biopsy [6], the age to start screening, and when to stop remain controversial, even among those who support screening $[11,12]$. Moreover, excessive PSA testing may lead to over-diagnosis and over-treatment with unhelpful and potentially harmful medication [13-15]. Against this background, genetic testing provides an attractive possibility for better risk-prediction of prostate cancer to serve as an aid in decision-making with respect to chemoprevention.

\section{Genotyping for Risk Prediction}

A number of single nucleotide polymorphisms (SNPs) have been associated with prostate cancer, but the strengths of association (odds ratios) have been modest [16-19]. The possibility of using a genetic test incorporating several SNPs $[20,21]$ to improve the predictive value and identify those at high risk of developing prostate cancer has therefore been greeted with great interest [22]. Zheng et al. [20] and Sun et al. [21] showed that when 5 SNPs, reported to be moderately associated with prostate cancer, were combined in a prediction model the association was strengthened considerably. However, the suggestion that a test based on these SNPs would be marketed soon has attracted considerable criticism [23-28]. The case illustrates well the problems associated with developing a genetic test and the difficulty in translating observed genetic associations into clinically useful tests [29]. In this commentary we highlight aspects of the development of the genetic screening test and its reported test characteristics. We assess its suitability for wider use and summarize critical comments made by others on the test's performance. We also discuss the proposed test in relation to the framework suggested by Khoury et al. [29] for assessing the phasing of translational research in genomic medicine.

\section{Test Development}

With microarrays, it is now relatively easy to compare, on a genome-wide basis, frequencies of gene variants among groups of cases (e.g., diseased or drug responder) and controls (e.g., healthy or drug non-responder). This approach, which has the advantage of scanning for informative genes not even previously thought to be involved in a disease, has lead to identification of associations between a range of SNPs and prostate cancer. The chromosomal region 8q24 [16-18;30], a region previously thought not to harbor genes, is particularly rich in this respect, as are 17q12 and 17q24.3 [31]: To develop their test, Zheng et al. [20] started off with 12 such SNPs spread across these regions, with $8 \mathrm{q} 24$ subdivided into 3 sub-regions. Their case-control study population consisted of 2,893 men with prostate cancer and 1,781 control subjects, all recruited from 4 geographical regions of Sweden covered by different cancer registries. They then undertook association tests, based on likelihood ratios of allelic prevalence, to estimate the strengths of association between SNP and disease and chose the one most informative SNP from each chromosomal region (one from each of the three 8q24 sub-regions and one each from 17q12 and 17q24.3) to finish up with those shown in table 1. The rationale for not simply choosing the most informative (i.e., associated with the smallest probability significance level) SNPs irrespective of chromosomal region was that there was considerable linkage disequilibrium between SNPs within each sub-region. As can be seen in table 1, the strengths of association for all 5 SNPs were modest, an odds ratio of 1 indicating equal distribution between cases and controls.

\section{Deriving Combined Strength}

The investigators' hypothesis was that by combining SNPs showing moderate associations the predictive value of the test would be improved. Given that previous studies had shown family history [32], age, and race to be associated with the risk of prostate cancer [4], they adjusted 
Table 2. Cumulative effect of associated factors on the risk of prostate cancer

$$
\text { Odds ratio }(95 \% \mathrm{CI})
$$

$\begin{array}{cc}\text { Number of associated genotypes } & \text { a }^{\mathrm{a}} \\ 0 & 1 \text { (reference subgroup) }^{2} \\ 1 & 1.50(1.18-1.92) \\ 2 & 1.96(1.54-2.49) \\ 3 & 2.21(1.70-2.89) \\ \geq 4 & 4.47(2.93-6.80)\end{array}$

Number of associated factors (5 SNPs and family history) ${ }^{\mathrm{b}}$

$0 \quad 1$ (reference subgroup)

$1 \quad 1.62(1.27-2.08)$

$2 \quad 2.07(1.62-2.64)$

$3 \quad 2.71(2.08-3.53)$

$4 \quad 4.76(3.31-6.84)$

$\geq 5 \quad 9.46(3.62-24.72)$

a Estimate adjusted for age, geographic region, and family history. ${ }^{\mathrm{b}}$ Estimate adjusted for age and geographic region.

for age and geographic region and included family history both as a covariate and as one factor along with the 5 SNPs in a 6 -factor statistical predictor. Pairwise tests for multiplicative interaction were non-significant for each possible pair of SNPs. It is seen from their estimates of effect (table 2) that combining the 5 SNPs provided a better predictor than the individual SNP or fewer SNPs in combination. The trend of increasing risk with increasing number of the 5 SNPs was statistically highly significant. Men who carried 5 or more of the 6 factors had an odds ratio of 9.46 (95\% CI 3.62-24.72) of developing prostate cancer compared to those who carried none of the risk factors. When family history was adjusted for, rather than formally introduced as a dichotomous factor, those having 4 or more of the 5 SNPs had an odds ratio of 4.47 (95\% CI 2.93-6.80) of prostate cancer. Although the odds ratio may appear high, it is important to note that markers with replicated highly significant odds ratios may still be poor classifiers $[33,34]$.

\section{Test Performance}

Given the cumulative association of the 5 genetic variants with prostate cancer, how well would a test based on the predictor be? Table 3 gives the performance characteristics of tests with alternative cut-offs, using the data reported by Zheng et al. [20]. The positive and negative

When Is a Genetic Test Ready for Prime Time? predictive values were calculated using the estimated cumulative probability of $14.5 \%$ by the age of 75 years, reported for the Swedish population [35], the same population selected by Zheng et al. [20] in their case-control study. The calculations are based on the prevalence of the various risk factors in Zheng's control group and reported in their table 4, and the population prevalence data on prostate cancer are from the Office of Statistics of Sweden [35].

From table 3 it can be seen that the test is of low discriminative accuracy with a high proportion of false positives. Thus with at least 2 of the factors (one SNP and family history), only about $21 \%$ of those tested positive would have prostate cancer. This is reflected in the poor area under the receiver operating characteristic (ROC) curve (AUC) of 0.63 . The AUC is a global measure of diagnostic accuracy. For a perfect test the AUC is 1 . The AUC gives the probability that test values for a randomly selected pair of prostate cancer and healthy control patients are correctly ordered.

Although the positive predictive value (probability of prostate cancer given a positive test result) increases with increasing number of factors, the performance is still unacceptable. Only $44 \%$ of positive test results accurately predicted prostate cancer with a model which included 5 or more factors, once population cumulative incidence is taken into account.

We also undertook a sensitivity analysis using a cumulative probability of $23.4 \%$ of prostate cancer by the age of 85 years [35] (table 4). The table also gives the likelihood ratios for the test, which again demonstrate, as with the results shown in table 3 , that performance of the proposed test at the population level would be quite inadequate to justify implementation in practice.

The results presented in table 1 of Zheng et al. [20] flatter the accuracy of the test since the odds ratio of the 5 -genetic-variant test compares the highest risk-category with the lowest risk-category [25]. The appropriate comparator is the general population. Figure 1 showing the odds ratios for the different strata illustrates the decreasing prevalence of the combined genotypes (reflected by the size of the squares and widening confidence intervals) as the number of SNPs increased. An increase in the odds ratio obtained by combining genotypes comes at the price of decreasing prevalence [27] and hence lowered test accuracy to the point of being of little use in practice (table 3). The group with 5 or more risk factors accounted for only $0.3 \%$ of the subjects in the control group and $1.4 \%$ of the prostate cancer group. This is reflected in the small area of the square symbol relative to the other categories 
Fig. 1. Stratum-specific odds ratio of presence of risk factors in case and control subjects. The pooled estimate simply reflects the distribution of risk factors across both the control and prostate cancer groups and should therefore be 1 as shown. The size of the squares reflects the weight of the stratum shown. The group with 1 factor is the most numerous, and the lines on either side of the squares define the $95 \%$ confidence intervals shown numerically on the right hand side.

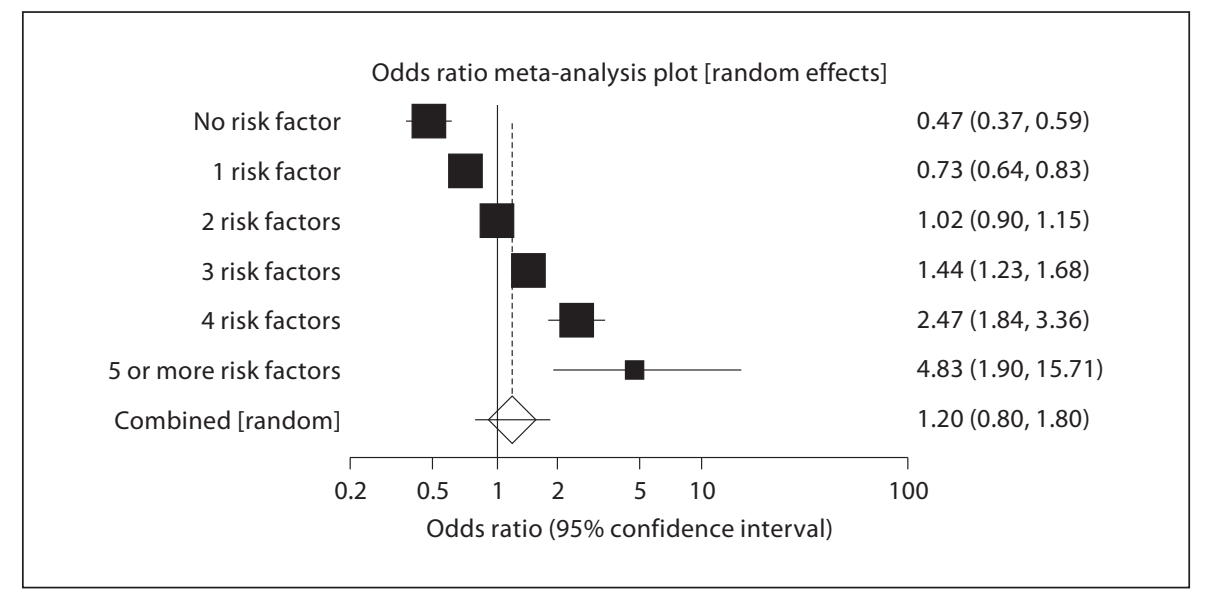

Table 3. Performance of alternative screening tests for prostate cancer based on the 6 risk factors included in the predictor of Zheng et al. [20] (5 SNPs and family history) using the cumulative Swedish population incidence of prostate cancer of $14.5 \%$ by the age of 75 years

\begin{tabular}{llcll}
\hline Risk factors & $\begin{array}{l}\text { Sensitivity } \\
\text { (detection rate) [\%] }\end{array}$ & $\begin{array}{l}\text { False positive rate } \\
\left(1-\text { specificity }^{\mathrm{b}}\right)[\%]\end{array}$ & $\begin{array}{l}\text { Positive predictive } \\
\text { value }^{\mathrm{c}}[\%]\end{array}$ & $\begin{array}{l}\text { Negative predictive } \\
\text { value }^{\mathrm{d}}[\%]\end{array}$ \\
\hline$\geq 1$ & $95.02(94.17-95.79)$ & $89.93(88.41-91.31)$ & $15.2(14.5-16.0)$ & $92.3(90.4-93.9)$ \\
$\geq 2$ & $68.13(66.40-69.83)$ & $56.31(53.93-58.66)$ & $17.0(16.1-18.0)$ & $89.0(88.0-89.9)$ \\
$\geq 3$ & $31.73(30.04-33.46)$ & $20.31(18.44-22.29)$ & $20.9(19.3-22.7)$ & $87.3(86.6-88.0)$ \\
$\geq 4$ & $9.54(8.49-10.67)$ & $3.76(2.91-4.77)$ & $30.0(25.8-34.4)$ & $86.2(85.5-86.9)$ \\
$\geq 5$ & $1.38(0.99-1.88)$ & $0.29(0.09-0.67)$ & $44.4(29.6-60.0)$ & $85.6(84.9-86.3)$ \\
\hline
\end{tabular}

Values in parentheses are the $95 \%$ confidence intervals. The calculations are based on the prevalence of the various risk factors in the control group of Zheng et al., [20] and reported in their table 4 and the population prevalence data on prostate cancer from the Office of Statistics of Sweden [35].

${ }^{\text {a }}$ Sensitivity $=\mathrm{P}($ test $+\mathrm{Ve} \mid$ disease $)$. This conditional probability statement can be read as probability of a positive test $(+\mathrm{Ve})$ result given that the person tested develops prostate cancer. The other test characteristics can be similarly read.

${ }^{\mathrm{b}}$ Specificity $=\mathrm{P}($ test $-\mathrm{Ve} \mid$ no disease $)$.

${ }^{\mathrm{c}}$ Positive predictive value $=\mathrm{P}($ disease $\mid$ test $+\mathrm{Ve})$.

${ }^{\mathrm{d}}$ Negative predictive value $=\mathrm{P}($ no disease $\mid$ test $-\mathrm{Ve})$.

Table 4. Performance of alternative screening tests for prostate cancer based on the 6 risk factors included in the predictor of Zheng et al. [20] (5 SNPs and family history) using the cumulative Swedish population incidence of prostate cancer of $23.4 \%$ up to the age of 85 years

\begin{tabular}{lllll}
\hline Risk factors & Positive predictive value [\%] & Negative predictive value [\%] & Likelihood ratio $(+)^{\mathrm{a}}$ & ${\text { Likelihood ratio }(-)^{\mathrm{b}}}^{\mathrm{a}}$ \\
\hline$\geq 1$ & $24.4(23.5-25.3)$ & $86.9(84.5-89.1)$ & $1.06(1.04-1.07)$ & $0.493(0.407-0.595)$ \\
$\geq 2$ & $27.0(25.9-28.1)$ & $81.8(80.6-82.9)$ & $1.21(1.17-1.25)$ & $0.730(0.684-0.778)$ \\
$\geq 3$ & $32.3(30.4-34.3)$ & $79.3(78.3-80.2)$ & $1.56(1.45-1.68)$ & $0.856(0.831-0.882)$ \\
$\geq 4$ & $43.6(39.3-48.1)$ & $77.7(76.8-78.5)$ & $4.76(2.14-3.00)$ & $0.940(0.927-0.953)$ \\
$\geq 5$ & $59.3(45.0-72.4)$ & $76.8(76.0-77.6)$ & $0.989(0.984-0.994)$ \\
\hline
\end{tabular}

Values in parentheses are the $95 \%$ confidence intervals. Other terms as defined in table 3.

${ }^{a}$ Likelihood ratio $(+)=\mathrm{P}($ test $+\mathrm{Ve} \mid$ disease $) / \mathrm{P}($ test $+\mathrm{Ve} \mid$ no disease $)$.

${ }^{\mathrm{b}}$ Likelihood ratio $(-)=\mathrm{P}($ test $-\mathrm{Ve} \mid$ disease $) / \mathrm{P}($ test $-\mathrm{Ve} \mid$ no disease $)$. 
and the wide confidence intervals of the estimates. In other words, while discrimination in terms of odds ratios improves as the number of SNPs included increases, test performance deteriorates rapidly. The positive predictive value (PPV), even with the use of cumulative prevalence of $23.4 \%$ to include those aged up to 85 years, was only $59 \%$ with 5 or more factors in the prediction model (table 4$)$.

\section{Population Attributable Risk (PAF)}

The population attributable fraction (population excess fraction) gives an estimate of the proportion disease burden that could be eliminated if the effects of the causal factor of interest were eliminated from the population [36]. Zheng et al. [20] estimated a PAF of 0.46 using their 6 risk factors. However, as pointed out by Severi et al. [37], none of the variants are known to be causal and therefore the impact of their removal is unknown. Moreover, given the impossibility of eliminating the variants, the significance of the PAF estimate is unclear especially as this was derived using the lowest risk group as reference instead of the overall population. Moreover, the SNPs explained just $2 \%$ of the effect seen for family-history, since adjustment for them reduced the effect estimate from 2.26 to 2.22 (95\% CI 1.83-2.68). This small improvement in predictive power is mirrored by the small change in AUC.

\section{Comparative Performance}

Although a proposed test does not predict prostate cancer risk as well as expected, it might still be a reasonable option if what is in current use is less good. Unfortunately, this is not the case for the 5-genetic-variant test. PSA measurement is considerably more predictive of prostate cancer risk. For example, Lilja et al. [2] have shown that a single PSA test at age 44 to 50 years has an AUC of 0.76 in predicting occurrence of prostate cancer up to 25 years later. A similar performance for PSA measurement is also seen in prediction of advanced prostate cancer $[3,38,39]$. Given that pathology laboratories of most major hospitals measure PSA routinely, it is difficult to see great value in the proposed 5-genetic-variant genotyping screen. The prevalence of the combined genotype is also too low (less than $1 \%$ and $2 \%$ in the control and prostate cancer population, respectively) for the test to be really useful for screening. In fact, adding the combined genotype to age, geographical region, and family history

When Is a Genetic Test Ready for Prime Time? improved the test performance (ROC-AUC) by about $2 \%$ (AUC increase from 0.61 to 0.63 ). Using the data presented by Zheng et al. [20] in their table 1, the ROC-AUC, using only the PSA and family history data, is considerably better at 0.92. Lilja et al. [2] and Vickers et al. [40] have reported an AUC of 0.76 for a single PSA measurement at 44 to 50 years of age in an unscreened population for the occurrence of prostate cancer up to 25 years later. In a US prospective study of over 8,500 men, assigned to the placebo arm of a randomized controlled trial, who were aged 55 years or older and followed up for 7 years, similar performance characteristics have been reported for PSA in men with an initial PSA level of $3.0 \mathrm{ng} / \mathrm{ml}$ or lower [41]. In both the Swedish and US studies, performance characteristics of the PSA screen improved with severity of the prostate cancer [38,41], but sensitivities decreased along with prevalence of the higher PSA levels [41] being no more than $20.5 \%$ at $4.1 \mathrm{ng} / \mathrm{ml} \mathrm{level}$. This demonstrates the important trade-offs and careful interpretation that need to be made when deciding and acting on the results of even a well-established test.

\section{Utility of the Test}

What are the implications of the results of the study of Zheng et al. [20] for the clinic? The balance of benefits and risks for screening for prostate cancer, even using the current gold standard PSA measurement, is unknown [8]. Chemoprevention even with the latest $5 \alpha$-reductase inhibitor finasteride is of uncertain benefit, with a hard trade-off required between an overall risk-reduction in prostate cancer against a possible higher risk of the more aggressive form and an increased incidence of sexual side-effects $[42,43]$. Moreover, there is as yet no consensus on modifiable prostate cancer risk factors suggesting that risk cannot be reliably reduced by lifestyle changes.

While we question the readiness of the test for clinical practice, we recognize the scientific endeavor of the investigators because they undertake some of the necessary steps in the translation of scientific insights in genomics to practical applications in the clinic. Khoury et al. [29] suggested that such translational research could be viewed within a continuum, which can be phased according to: a phase 1 where research aims to move a genome-based discovery into a candidate health application (in this case testing for a set of SNPs for predicting prostate cancer); a phase 2 concerned with assessing the value of a genomic application for health practice leading to appropriate evidence-based guidelines; a phase 3 which attempts to 
move evidence-based guidelines into health practice; and a phase 4 which aims to evaluate the 'real world' health outcome of the application. So where in this phasing of translational research in genomics should the work of Zheng et al. [20] be placed? Our assessment is that the work so far is still straddling phases 1 and 2, because these phases should probably be regarded as nodes in an iterative loop that may or may not lead to a clinically useful test. However, given the concerns about the wider aspects which impinge on clinical utility, perhaps a tentative phase 2 assessment of the proposed test must be that it is not clinically useful as yet, and it does not add to what can be obtained with PSA testing.

It is worth recognizing that for adoption of a new test such as the proposed prostate cancer test for prime-time use, in addition to the test (metrics) and patient-specific (harm-benefit) factors considered and discussed above, there are also the wider societal aspects, such as cost-effectiveness, to be carefully considered in establishing innovation policy [44].

Better ways to estimate risk of prostate cancer are needed. Molecular and genetic analyses carry considerable hope both for risk estimation and prognostication of established disease. A question in the minds of all policymakers is whether a proposed new test is ready for adoption in routine clinical practice, or 'ready for prime time' [45]. In our assessment we define prime time as circumstances in which PSA testing is currently used and appropriate for adoption by funders. The study of Zheng et al. [20] is promising but the answer is clearly that the technical performance of the test, as judged by the relevant metrics, is not yet adequate. The developers of the 5-geneticvariants test rightly argue that new risk variants are being identified and the test characteristics will improve [46]. Indeed in an updated report on their test, the authors include 11 risk-alleles or family history [47]. Little improve- ment was obtained relative to the 5 risk-allele model, with an ROC of 0.65 compared to 0.63 , thereby emphasizing the problems highlighted in this critical appraisal. Although statistically different AUCs were obtained, the corresponding values for a prediction model using age alone and another using age and family history only were 0.58 and 0.61 , respectively. Therefore, inclusion of the risk SNPs produced only a marginal improvement irrespective of whether 5 or 11 SNPs were used. An even more difficult challenge is to demonstrate the clinical utility of the test [24]. It is worth mentioning that although this was not the intent of the proposed test, the 5 SNPs cannot be used to make prognoses as the strengths of association with aggressive and less aggressive forms of the disease appear similar.

\section{Conclusion}

The benefit of screening for prostate cancer is still uncertain even with PSA measurement. Our analysis suggests that the proposed 5-genetic-variant test for risk estimation of prostate cancer is inadequate. Addition of a further 6 risk-alleles so far identified led to only marginal improvement in test performance. For now the rational inference about the utility of the test must be interesting, but a long way to go' before it is ready for adoption by funders.

\section{Acknowledgments}

We would like to thank Dr. Ralph J. Coates at the Centers for Disease Control and Prevention, Atlanta, and Dr. Ron Zimmern at the PHG Foundation, Cambridge for their generous help with critical comments on our contribution prior to submission.

\section{References}

1 Burke W, Zimmern RL: Ensuring the appropriate use of genetic tests. Nat Rev Genet 2004;5:955-959.

-2 Lilja H, Ulmert D, Björk T, Becker C, Serio AM, Nilsson JA, Abrahamsson PA, Vickers AJ, Berglund G: Long-term prediction of prostate cancer up to 25 years before diagnosis of prostate cancer using prostate kallikreins measured at age 44 to 50 years. J Clin Oncol 2007;25:431-436.

-3 Ulmert D, Serio AM, O‘Brien MF, Becker C, Eastham JA, Scardino PT, Björk T, Berglund G, Vickers AJ, Lilja H: Long-term prediction of prostate cancer: prostate-specific antigen (PSA) velocity is predictive but does not improve the predictive accuracy of a single PSA measurement 15 years or more before cancer diagnosis in a large, representative, unscreened population. J Clin Oncol 2008; 26:835-841.

4 Gronberg H: Prostate cancer epidemiology. Lancet 2003;361:859-864.

5 Thompson IM, Pauler DK, Goodman PJ, Tangen CM, Lucia MS, Parnes HL, Minasian LM, Ford LG, Lippman SM, Crawford ED, Crowley JJ, Coltman CA Jr: Prevalence of prostate cancer among men with a prostate-specific antigen level $<$ or $=4.0 \mathrm{ng}$ per milliliter. N Engl J Med 2004;350:2239_ 2246. 
6 Canby-Hagino E, Hernandez J, Brand TC, Troyer DA, Higgins B, Ankerst DP, Thompson IM, Leach RJ, Parekh DJ: Prostate cancer risk with positive family history, normal prostate examination findings, and PSA less than $4.0 \mathrm{ng} / \mathrm{ml}$. Urology 2007;70:748-752.

-7 Ruckle HC, Klee GG, Oesterling JE: Prostate-specific antigen: concepts for staging prostate cancer and monitoring response to therapy. Mayo Clin Proc 1994;69:69-79.

$>8$ U.S. Preventive Services Task Force: Screening for prostate cancer: recommendation and rationale. Ann Intern Med 2002;137: 915-916.

-9 Weir HK, Thun MJ, Hankey BF, Ries LA, Howe HL, Wingo PA, Jemal A, Ward E, Anderson RN, Edwards BK: Annual report to the nation on the status of cancer, 19752000 , featuring the uses of surveillance data for cancer prevention and control. J Natl Cancer Inst 2003;95:1276-1299.

$\checkmark 10$ Sirovich BE, Schwartz LM, Woloshin S: Screening men for prostate and colorectal cancer in the United States: does practice reflect the evidence? JAMA 2003;289:14141420.

11 Catalona WJ, Loeb S, Han M: Viewpoint: expanding prostate cancer screening. Ann Intern Med 2006;144:441-443.

$\checkmark 12$ Hoffman RM: Viewpoint: limiting prostate cancer screening. Ann Intern Med 2006;144: 438-440.

$\checkmark 13$ Barry MJ: The PSA Conundrum. Arch Intern Med 2006;166:7-8.

14 Yao SL, Lu-Yao G: Understanding and appreciating overdiagnosis in the PSA era. J Natl Cancer Inst 2002;94:958-960.

15 Rosner W: Proscar and propecia - a therapeutic perspective. J Clin Endocrinol Metab 2004;89:3096-3098.

16 Haiman CA, Patterson N, Freedman ML, Myers SR, Pike MC, Waliszewska A, Neubauer J, Tandon A, Schirmer C, McDonald GJ, Greenway SC, Stram DO, Le Marchand L, Kolonel LN, Frasco M, Wong D, Pooler LC, Ardlie K, Oakley-Girvan I, Whittemore AS, Cooney KA, John EM, Ingles SA, Altshuler D, Henderson BE, Reich D: Multiple regions within $8 \mathrm{q} 24$ independently affect risk for prostate cancer. Nat Genet 2007;39: 638-644.

-17 Yeager M, Orr N, Hayes RB, Jacobs KB, Kraft P, Wacholder S, Minichiello MJ, Fearnhead P, Yu K, Chatterjee N, Wang Z, Welch R, Staats BJ, Calle EE, Feigelson HS, Thun MJ, Rodriguez C, Albanes D, Virtamo J, Weinstein S, Schumacher FR, Giovannucci E, Willett WC, Cancel-Tassin G, Cussenot O, Valeri A, Andriole GL, Gelmann EP, Tucker M, Gerhard DS, Fraumeni JF Jr, Hoover R, Hunter DJ, Chanock SJ, Thomas G: Genome-wide association study of prostate cancer identifies a second risk locus at $8 \mathrm{q} 24$. Nat Genet 2007;39:645-649.
Gudmundsson J, Sulem P, Manolescu A, Amundadottir LT, Gudbjartsson D, Helgason A, Rafnar T, Bergthorsson JT, Agnarsson BA, Baker A, Sigurdsson A, Benediktsdottir KR, Jakobsdottir M, Xu J, Blondal T, Kostic J, Sun J, Ghosh S, Stacey SN, Mouy M, Saemundsdottir J, Backman VM, Kristjansson K, Tres A, Partin AW, Albers-Akkers MT, Godino-Ivan Marcos J, Walsh PC, Swinkels DW, Navarrete S, Isaacs SD, Aben KK, Graif $\mathrm{T}$, Cashy J, Ruiz-Echarri M, Wiley KE, Suarez BK, Witjes JA, Frigge M, Ober C, Jonsson E, Einarsson GV, Mayordomo JI, Kiemeney LA, Isaacs WB, Catalona WJ, Barkardottir RB, Gulcher JR, Thorsteinsdottir U, Kong A, Stefansson K: Genome-wide association study identifies a second prostate cancer susceptibility variant at $8 \mathrm{q} 24$. Nat Genet 2007;39:631-637.

19 Zheng SL, Sun J, Cheng Y, Li G, Hsu FC, Zhu Y, Chang BL, Liu W, Kim JW, Turner AR, Gielzak M, Yan G, Isaacs SD, Wiley KE, Sauvageot J, Chen HS, Gurganus R, Mangold LA, Trock BJ, Gronberg H, Duggan D, Carpten JD, Partin AW, Walsh PC, Xu J, Isaacs WB: Association between two unlinked loci at $8 \mathrm{q} 24$ and prostate cancer risk among European Americans. J Natl Cancer Inst 2007; 99:1525-1533.

20 Zheng SL, Sun J, Wiklund F, Smith S, Stattin P, Li G, Adami HO, Hsu FC, Zhu Y, Bälter K, Kader AK, Turner AR, Liu W, Bleecker ER, Meyers DA, Duggan D, Carpten JD, Chang BL, Isaacs WB, Xu J, Grönberg H: Cumulative association of five genetic variants with prostate cancer. N Engl J Med 2008;358:910 919.

21 Sun J, Chang BL, Isaacs SD, Wiley KE, Wiklund F, Stattin P, Duggan D, Carpten JD, Trock BJ, Partin AW, Walsh PC, Grönberg H, $\mathrm{Xu}$ J, Isaacs WB, Zheng SL: Cumulative effect of five genetic variants on prostate cancer risk in multiple study populations. Prostate 2008;68:1257-1262.

22 Gelmann EP: Complexities of prostate-cancer risk. N Engl J Med 2008;358:961-963.

23 Kolata G: $\$ 300$ to learn the risk of cancer of the prostate. New York Times 2008, January 17.

24 Coates RJ, Khoury MJ, Gwinn M: Five genetic variants associated with prostate cancer. N Engl J Med 2008;358:2738.

25 Janssens AC, van Duijn CM: Five genetic variants associated with prostate cancer (Letter). N Engl J Med 2008;358:2739.

26 Gartner CE, Barendregt JJ, Hall WD: Five genetic variants associated with prostate cancer (Letter). N Engl J Med 2008;358: 2738-2739.

27 Thorat MA: Five genetic variants associated with prostate cancer (Letter). N Engl J Med 2008;358:2740.

28 Eisinger F: Five genetic variants associated with prostate cancer (Letter). N Engl J Med 2008;358:2740-2741.
9 Khoury MJ, Gwinn M, Yoon PW, Dowling N, Moore CA, Bradley L: The continuum of translation research in genomic medicine: how can we accelerate the appropriate integration of human genome discoveries into health care and disease prevention? Genet Med 2007;9:665-674.

- 30 Amundadottir LT, Sulem P, Gudmundsson J, Helgason A, Baker A, Agnarsson BA, Sigurdsson A, Benediktsdottir KR, Cazier JB, Sainz J, Jakobsdottir M, Kostic J, Magnusdottir DN, Ghosh S, Agnarsson K, Birgisdottir B, Le Roux L, Olafsdottir A, Blondal T, Andresdottir M, Gretarsdottir OS, Bergthorsson JT, Gudbjartsson D, Gylfason A, Thorleifsson G, Manolescu A, Kristjansson K, Geirsson G, Isaksson H, Douglas J, Johansson JE, Bälter K, Wiklund F, Montie JE, Yu X, Suarez BK, Ober C, Cooney KA, Gronberg H, Catalona WJ, Einarsson GV, Barkardottir RB, Gulcher JR, Kong A, Thorsteinsdottir U, Stefansson K: A common variant associated with prostate cancer in European and African populations. Nat Genet 2006;38: 652-658.

31 Gudmundsson J, Sulem P, Steinthorsdottir V, Bergthorsson JT, Thorleifsson G, Manolescu A, Rafnar T, Gudbjartsson D, Agnarsson BA, Baker A, Sigurdsson A, Benediktsdottir KR, Jakobsdottir M, Blondal T, Stacey SN, Helgason A, Gunnarsdottir S, Olafsdottir A, Kristinsson KT, Birgisdottir B, Ghosh S, Thorlacius S, Magnusdottir D, Stefansdottir G, Kristjansson K, Bagger Y, Wilensky RL, Reilly MP, Morris AD, Kimber CH, Adeyemo A, Chen Y, Zhou J, So WY, Tong PC, Ng MC, Hansen T, Andersen G, Borch-Johnsen $\mathrm{K}$, Jorgensen T, Tres A, Fuertes F, RuizEcharri M, Asin L, Saez B, van Boven E, Klaver S, Swinkels DW, Aben KK, Graif T, Cashy J, Suarez BK, van Vierssen Trip O, Frigge ML, Ober C, Hofker MH, Wijmenga C, Christiansen C, Rader DJ, Palmer CN, Rotimi C, Chan JC, Pedersen O, Sigurdsson G, Benediktsson R, Jonsson E, Einarsson GV, Mayordomo JI, Catalona WJ, Kiemeney LA, Barkardottir RB, Gulcher JR, Thorsteinsdottir U, Kong A, Stefansson K: Two variants on chromosome 17 confer prostate cancer risk, and the one in TCF2 protects against type 2 diabetes. Nat Genet 2007;39:977-983.

-32 Johns LE, Houlston RS: A systematic review and meta-analysis of familial prostate cancer risk. BJU Int 2003;91:789-794.

-33 Lu Q, Elston RC: Using the optimal receiver operating characteristic curve to design a predictive genetic test, exemplified with type 2 diabetes. Am J Hum Genet 2008;82:641651.

34 Jakobsdottir J, Gorin MB, Conley YP, Ferrell RE, Weeks DE: Interpretation of genetic association studies: markers with replicated highly significant odds ratios may be poor classifiers. PLoS Genet 2009;5:e1000337. 
35 Centre for Epidemiology. Cancer incidence in Sweden 2004. Stockholm: The National Board of Health and Welfare, 2005. Available at http://www.socialstyrelsen.se/NR/rdonlyres/A23BCC9E-23B5-4747-AAA9-23BB9 CDF4B75/4753/20054291.pdf.

- 36 Greenland S, Robins JM: Conceptual problems in the definition and interpretation of attributable fractions. Am J Epidemiol 1988; 128:1185-1197.

37 Severi G, Byrnes GB, Hopper JL: Five genetic variants associated with prostate cancer. N Engl J Med 2008;358:2739-2740.

38 Ulmert D, Cronin AM, Björk T, O'Brien MF, Scardino PT, Eastham JA, Becker C, Berglund G, Vickers AJ, Lilja H: Prostate-specific antigen at or before age 50 as a predictor of advanced prostate cancer diagnosed up to 25 years later: a case-control study. BMC Med 2008;6:6.
39 Lilja H, Ulmert D, Vickers AJ: Prostate-specific antigen and prostate cancer: prediction, detection and monitoring. Nat Rev Cancer 2008;8:268-278.

40 Vickers A, Lilja H, Scardino P: Five genetic variants associated with prostate cancer. N Engl J Med 2008;358:2740.

41 Thompson IM, Ankerst DP, Chi C, Lucia MS, Goodman PJ, Crowley JJ, Parnes HL, Coltman CA Jr: Operating characteristics of prostate-specific antigen in men with an initial PSA level of $3.0 \mathrm{ng} / \mathrm{ml}$ or lower. JAMA 2005;294:66-70.

Thompson IM, Goodman PJ, Tangen CM, Lucia MS, Miller GJ, Ford LG, Lieber MM, Cespedes RD, Atkins JN, Lippman SM, Carlin SM, Ryan A, Szczepanek CM, Crowley JJ, Coltman CA Jr: The influence of finasteride on the development of prostate cancer. $\mathrm{N}$ Engl J Med 2003;349:215-224.
43 Scardino PT: The prevention of prostate cancer - the dilemma continues. N Engl J Med 2003;349:297-299.

44 Guston DH: Innovation policy: not just a jumbo shrimp. Nature 2008;454:940-941.

45 Shurin SB, Nabel EG: Pharmacogenomics ready for prime time? N Engl J Med 2008; 358:1061-1063.

$46 \mathrm{Xu}$ J, Isaacs WB, Gronberg H: Five genetic variants associated with prostate cancer. $\mathrm{N}$ Eng J Med 2008;358:2741.

47 Zheng SL, Sun J, Wiklund F, Gao Z, Stattin P, Purcell LD, Adami HO, Hsu FC, Zhu Y, Adolfsson J, Johansson JE, Turner AR, Adams TS, Liu W, Duggan D, Carpten JD, Chang BL, Isaacs WB, Xu J, Grönberg H: Genetic variants and family history predict prostate cancer similar to prostate-specific antigen. Clin Cancer Res 2009;15:11051111 . 